\title{
The Impact of the ITI International Team for Implantology on Implant Dentistry: A Retrospective and Descriptive Analysis of $\mathbf{3 0}$ Years of Research Support
}

\author{
Rafael Lazarin, DDS, MSc ${ }^{1} /$ Supriya Ebenezer, BDS, MDS 1 /Kati Benthaus, DDS ${ }^{2}$ / \\ Martin Schimmel, DMD, MAS, Prof Dr Med Dent ${ }^{3}$
}

\begin{abstract}
Purpose: The purpose of this study was to analyze the projects submitted to the ITI International Team for Implantology for funding and the scientific publications ensuing from these projects, over a period of 30 years. Materials and Methods: This analysis was performed based on information available in the database of the ITI. For each project, data related to institution, country of origin, and grant status (financed or rejected) were extracted. For the financed projects, the grant amount and number of publications were recorded. Publications were searched independently by two investigators. For all publications, the study topic, study design, and citation number were recorded. Results: From a total of 1,372 submitted projects from 51 different countries and 308 different institutions, 514 (37.46\%) were financed by the ITI. This amounts to more than CHF 52 million invested in favor of implant dentistry and related fields. A total of 552 publications (including original research and reviews) were identified related to these projects, with the majority being in vitro studies ( $n=198$ ), and the most common topic researched was implant surface modification ( $n=134)$. The United States was the country and the University of Bern was the institution with the largest number of financed projects and published papers. Conclusion: This analysis revealed that the ITI has been actively supporting research in the field of implant dentistry and related areas globally. Several concepts in present-day implantology are based on literature from ITI-funded projects. INT J ORAL MAXILLOFAC IMPLANTS 2020;35:e1-e13. doi: 10.11607/jomi.7799
\end{abstract}

Keywords: bibliometrics, dental implants, evidence-based dentistry, funding, implant dentistry, publications, research projects

W ith the introduction of implants into dentistry in 1965 by Brånemark, a new treatment perspective emerged for stabilizing dentures and replacement

\footnotetext{
${ }^{1}$ Department of Oral Surgery and Stomatology, School of Dental Medicine, University of Bern, Bern, Switzerland. ${ }^{2}$ ITI International Team for Implantology, Basel, Switzerland. ${ }^{3}$ Division of Gerodontology and Removable Prosthodontics, University Clinics of Dental Medicine, University of Geneva, Geneva, Switzerland; Department of Reconstructive Dentistry and Gerodontology, School of Dental Medicine, University of Bern, Bern, Switzerland.
}

The first two authors contributed equally to this study.

Correspondence to: Dr Rafael Lazarin, Department of Oral Surgery and Stomatology, School of Dental Medicine, University of Bern, Freiburgstrasse 7, 3010 Bern, Switzerland. Email: lazarinrafael@gmail.com

Submitted May 3, 2019; accepted July 30, 2019.

(O2020 by Quintessence Publishing Co Inc. of missing teeth. Although originally described as a treatment modality for fully edentulous patients, ${ }^{1,2}$ treatment with dental implants has become an accepted option worldwide, presenting predictable and long-term results. ${ }^{1-11}$ Implants have become a reliable option for stabilizing dentures and tooth replacement not only for completely edentulous situations, $, 8,9,12-15$ but also for the treatment of partially edentulous $5,6,8,12,14,16,17$ and single-tooth-gap situations. $3,4,7,10,11,18,19$

Since the early preclinical and clinical studies of osseointegrated dental implants in the 1960s to $1980 s^{1,2,20-22}$ treatment concepts, protocols, techniques, and materials have undergone development. Following the trends of researchers and clinicians over the past five decades, it is clear that there has been a continuous scientific evolution in implantology. ${ }^{23}$ With this increased interest in implantology, there has been a surge in the number of publications focusing on implant-related research from the 1990 s. $^{24} \mathrm{~A}$ recent study indicates a growth rate of $39 \%$ in the number of publications during a time period of 5 years. ${ }^{25} \mathrm{~A}$ significant 
addition to implant literature (ie, publications) indicates investments in implant research. The implant market also has seen a boom in recent years, either as a result of published long-term success of implant solutions for missing teeth or due to the money invested in the market. An increase in publications coincided with an increase in international collaborations. ${ }^{25,26}$

An increase in implant research and collaborations indicates that there has been increased funding in this field. Research funding has different sources such as foundations, industry, governmental, and research institutes/university sponsorship. ${ }^{26,27}$ Knowledge and disclosure of funding sources are critical, as they might influence results of the study, creating bias. This knowledge is essential before extrapolating the results into facts, as industry-sponsored trials provided favorable results compared with non-industry-associated trials. ${ }^{28}$

Recognizing the importance of conducting dental research independently, the ITI International Team for Implantology Association, a nonprofit organization, was founded in 1980 by 12 experts from the field of implant dentistry. The mission was to promote and disseminate knowledge in all aspects of implant dentistry through research, development, and education for the benefit of the patients. In 1988, the ITI Foundation was established by Fritz Straumann and André Schoeder to provide financial assistance for preclinical and clinical research projects related to implant dentistry and oral tissue regeneration. Decisions related to funding of projects were made by the Research Committee of the Foundation. In its early days, the ITI contributed significantly to the research and development of implant design and implant surfaces, and these contributions have continued to evolve with the change in treatment approach and technology. Since its very early days, the ITI has enjoyed a unique relationship with Straumann, a global leader in implant, restorative, and regenerative dentistry. While the ITI is dedicated to advancing and promoting clinical expertise in implant dentistry through measures focused on education and research, Straumann's core competency is the development and marketing of commercial products in this field. Both organizations share the goal of developing optimal treatment solutions to the benefit of patients. Straumann supports the ITI financially.

Over the past 30 years of its existence, it is estimated that the ITI has financially supported more than 500 projects from different collaborating researchers and clinicians worldwide. It currently serves as one of the largest organizations supporting implant research, having invested a total of CHF 27.6 million (for 232 different projects) by 2006, and these financed projects have resulted in 206 publications in peer-reviewed journals. ${ }^{29}$ The purpose of the present study was to identify, analyze, and describe the characteristics of the projects submitted to the ITI International Team for Implantology and the scientific contributions in terms of publications of the ITI-funded research projects over a period of 30 years.

\section{MATERIALS AND METHODS}

This retrospective and descriptive analysis was performed based on information available in the electronic database of the ITI International Team for Implantology used to store all information related to the "research funding program." This electronic database (FileMaker Pro 7) contains the data of all projects submitted to the ITI for funding (since 1988) and is constantly updated with the latest information and publications of each project funded provided by the respective principal applicant. The information collected from this database was complemented with additional data obtained through a hand-search analysis of the hard copy of the files stored at the ITI Headquarters, Basel, Switzerland.

Briefly, since 1988, the ITI Research Committee (https://www.iti.org/about/leadership\#research-committee) met biannually to evaluate individually and collectively each project submitted, to decide if the project could be funded or not. Selection of projects for funding followed certain established criteria. Currently, a total of US \$2.2 million/year is allocated for funding different research projects from all over the world. Following each meeting, the ITI Database FileMaker Pro 7 was updated with the project information and the Committee decision by the administrative department of the ITI Headquarters. Once the project was approved and financed by the ITI, the principal applicant was expected to periodically report on the progress of the project until it was completed. Postcompletion, the applicant was required to furnish complete details of the ensuing publication. All applicants were requested to state an acknowledgment to the ITI Foundation for financial support. The ITI Database FileMaker Pro 7 was constantly updated with all information related to publications from the projects as well.

For the present analysis, data from the year 1988 up to December 2018 were considered. The data extraction was conducted in two different parts as described in the sequence: (1) project-related information and (2) publication-related information.

\section{Project-Related Information}

Information from the ITI Database FileMaker Pro 7 related to projects submitted to the ITI from 1988 until December 2018 was extracted by two examiners (R.L. 
and S.E.) and stored in a standardized table in a spreadsheet program (Microsoft Excel 2011, Microsoft). The extracted data were related to:

- Project number (numbered sequentially as per the database according to the order of submission)

- Year in which the project was submitted (ie, project year)

- Institutional affiliation and country of the main applicant: wherever possible, university-related affiliation was recorded ("School," "College," "Department," and "Clinics" were all registered under the affiliated university name). In some cases, non-university-based institutes were stated. In cases where there was insufficient information to identify the main author's university/institutional affiliation, it was considered as "private practice."

- Title of the project

- Project type: Projects were categorized in the database as "new project" if the project was being submitted for the first time to the ITI, "continuing project" if the project was a continuation of a previous financed project, or a "revised project" if a previous rejected project was resubmitted with some changes.

- Grant status: As per the decision of the Research Committee, the project was either "financed" by the ITI Foundation or it was "rejected."

- Grant amount: The amount requested for the project could be expressed in one of the following currencies: Swiss francs (CHF), Euro $(€)$, British pounds (£), US dollar (US\$), Australian dollar (AU\$), or Japanese yen ( $¥)$. In some instances, the requested amount varied from the amount the ITI agreed to finance, and hence, only the latter was considered. The "financed" projects were classified as "small grant" $(<$ CHF $50,000.00$ or equivalent amount in different currency) or a "large grant" (> CHF 50,000.00 or equivalent amount in different currency) based on the amount of money provided. For final analysis, all the values were converted to CHF.

- Project status: This referred to project completion. The project was either "completed" or considered "ongoing" based on the project status until December 2018.

- Articles published: This stated if a funded project resulted in publications or not, and how many publications in scientific journals the project had resulted in. Publications stored in the database for each project (provided by the principal investigator of each project) were used. In cases where no publications were provided, an additional search for articles on the Internet using the names of investigators from the research group and the topic of the financed project was done. As requested by the ITI, all the publications resulting from a financed project had to include a footnote stating that the project was supported by a grant from the ITI Foundation for the Promotion of Oral Implantology, Switzerland. The additional publications were identified based on the presence of this acknowledgment related to funding. If articles were not present on the ITI database or if they did not carry the acknowledgment despite being from the same research group and with the same topic, they were not included in the analysis. Textbook chapters, posters, and conference abstracts were not considered.

\section{Publication-Related Information}

For all the publications available and published in scientific journals until December 2018, a full-text analysis was performed, and the following data were extracted:

- Year of publication

- Journal of publication

- Authors' names and institutional affiliation

- Country and name of the institution in which the study was conducted: For the purpose of the research and further descriptive analysis, this was considered as the place of the origin of the publication. In case this information was not available in the manuscript and/or the study was conducted in more than one center, the country and affiliation of the first author was adopted. Again, in the case of more than one affiliation, the first affiliation provided by the author was considered.

- International collaboration: This was defined in the presence of authors affiliated with institutions from more than one country or authors from different countries.

- Publication title

- Study topic: This was adapted from Alarcón and coworkers (2017), ${ }^{30}$ who classified topics based on results of consensus meetings of the ITI International Team for Implantology and the European Association for Osseointegration (EAO). For the present analysis, this classification was modified to be more specific. The classification of study topic was made based on the main objective of the study.

- Study design: This was adopted from Alarcón and coworkers $^{30}$ and further adapted using the Cochrane Collaboration Glossary (https:// community.cochrane.org/glossary).

- Citation number: This information was obtained using the online platform Institute for Science Information (ISI) Web of Science (www. webofknowledge.com) accessed at the University 


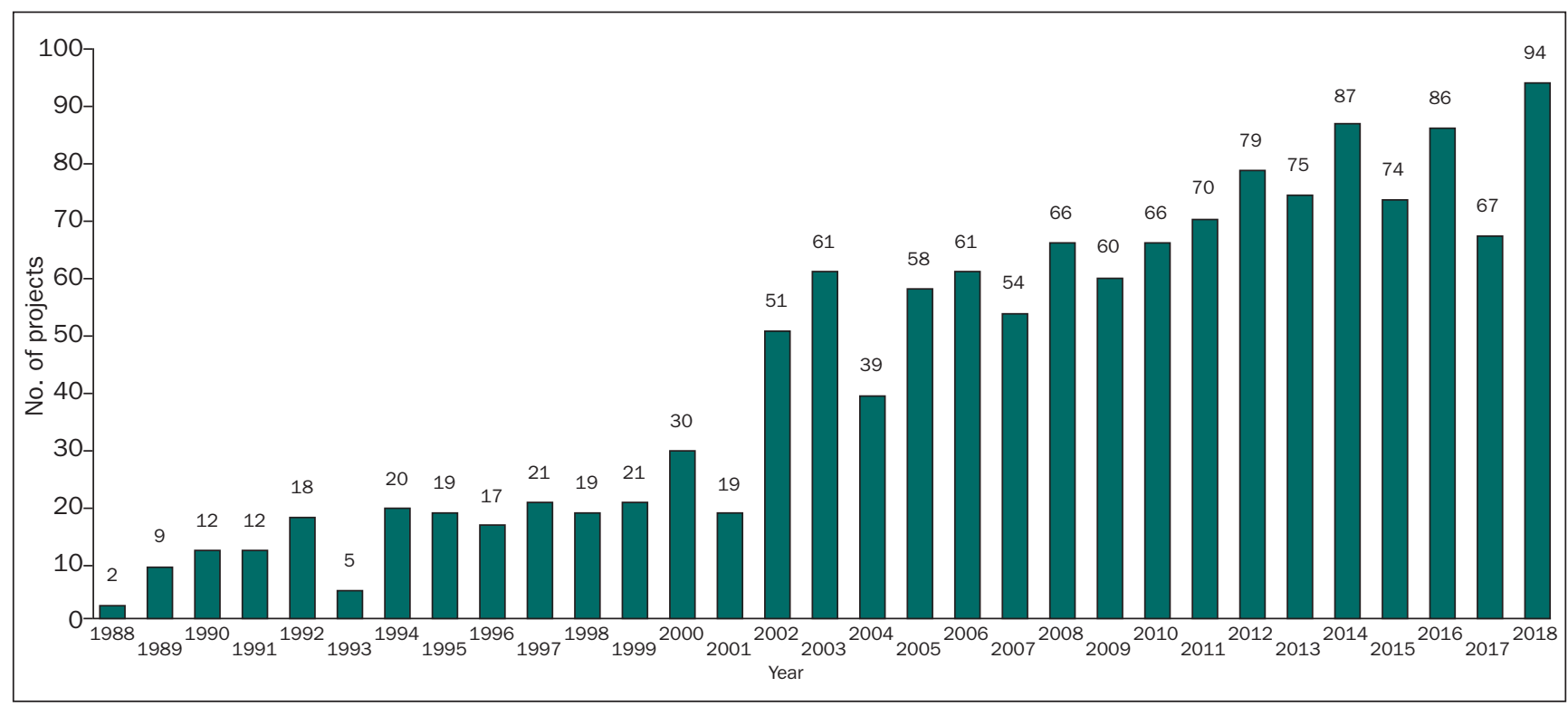

Fig 1 Number of projects submitted to the ITI International Team for Implantology for funding per year.

of Bern. The total number of citations and the average citations per year, indexed in this platform, was recorded from the date of publication until December 31, 2018, for each paper.

All the aforementioned data were collected and entered into a standardized table in a spreadsheet program (Microsoft Excel 2011, Microsoft) independently by two examiners (R.L., S.E.). Any disagreement was resolved by discussion between the examiners until consensus was achieved.

\section{RESULTS}

\section{Project-Related Information}

Submitted Projects. Since 1988, a total of 1,372 research projects were submitted to the ITI for funding. These applications came from 51 different countries and 308 different affiliations. The number of projects submitted per year, the top 10 countries, and the top 10 affiliations who submitted research projects are represented, respectively, by Fig 1 and Tables 1 and 2 . Appendix Tables 1 and 2 show the entire list of countries and affiliations, respectively.

Of all projects, $37.46 \%$ (514 projects) were financed (accepted), and the rest, $62.54 \%$ (858 projects), were rejected.

\section{Financed Projects}

Of the 514 financed (accepted) projects, the University of Bern (57 projects, $11.09 \%$ of all financed projects), University of Geneva (23 projects, $4.47 \%$ ), and University of Texas Health Science Center at San Antonio (22 projects, $4.28 \%$ ) were the three most frequent universities supported. The three most frequent countries to receive grants were Switzerland (111 projects, 21.60\% of all financed projects), United States (103 projects, $20.04 \%$ ), and Germany (77 projects, $14.98 \%$ ). Overall, the financed projects were from 146 different institutional affiliations and 31 different countries. The number of projects financed per year is demonstrated in Fig 2. Appendix Tables 3 and 4 show the list of all countries and affiliations, respectively, related to the financed projects.

\section{Grant Amount}

From 1988 until 2018, the ITI Foundation has invested a total of CHF 52,083,540.18 into implant and related research. As an average per year, the total amount as support to different research groups worldwide was CHF 1.7 million.

\section{Project Status}

Until December 2018, 74.12\% (381 projects) were regarded as completed, while $25.88 \%$ (133 projects) were still ongoing. Regardless of the project status, $62 \%$ of the projects had resulted in at least one scientific publication (Table 3). Taking into account the project status, approximately $80 \%$ of the completed projects had publications compared with $15 \%$ of the ongoing projects (Table 3).

\section{Project Type}

Out of the 514 financed projects, 421 (81.91\%) were new applications, $24(4.67 \%)$ were continued projects from a previous submission, $64(12.45 \%)$ were revised applications, and in 5 projects $(0.97 \%)$, the status was not reported. 


\begin{tabular}{llccc} 
Table $\mathbf{1}$ & $\begin{array}{l}\text { Number of Projects Submitted and Financed and Percentage of Projects Financed from the } \\
\mathbf{1 0} \text { Most Frequent Countries That Applied to the ITI International Team for Implantology for } \\
\text { a Research Grant }\end{array}$ \\
\cline { 3 - 5 } Rank & Country & Submitted & No. of projects & Financed rate \\
\hline 1 & USA & 229 & 103 & $44.98 \%$ \\
\hline 2 & Germany & 223 & 77 & $34.53 \%$ \\
\hline 3 & Switzerland & 184 & 111 & $60.33 \%$ \\
\hline 4 & China & 87 & 24 & $27.59 \%$ \\
\hline 5 & Netherlands & 59 & 17 & $28.81 \%$ \\
\hline 6 & Italy & 56 & 20 & $35.71 \%$ \\
\hline 7 & UK & 54 & 16 & $29.63 \%$ \\
\hline 8 & Brazil & 39 & 9 & $23.08 \%$ \\
\hline 9 & India & 39 & 7 & $17.95 \%$ \\
\hline 10 & Austria & 38 & 15 & $39.47 \%$ \\
\hline
\end{tabular}

\begin{tabular}{|c|c|c|c|c|}
\hline \multirow[t]{2}{*}{ Table 2} & \multicolumn{4}{|c|}{$\begin{array}{l}\text { Number of Projects Submitted and Financed and Percentage of Projects Financed from the } \\
10 \text { Most Frequent Institutions That Applied to the ITI International Team for Implantology } \\
\text { for a Research Grant }\end{array}$} \\
\hline & \multirow[b]{2}{*}{ Institution } & \multicolumn{3}{|c|}{ No. of projects } \\
\hline Rank & & Submitted & Financed & Financed rate \\
\hline 1 & University of Bern & 85 & 57 & $67.06 \%$ \\
\hline 2 & Private practice & 53 & 9 & $16.98 \%$ \\
\hline 3 & University of Mainz & 42 & 15 & $35.71 \%$ \\
\hline 4 & University of Erlangen-Nuremberg & 36 & 18 & $50 \%$ \\
\hline 5 & University of Geneva & 32 & 23 & $71.88 \%$ \\
\hline 6 & University of Vienna & 31 & 13 & $41.94 \%$ \\
\hline 7 & Harvard University & 30 & 20 & $66.67 \%$ \\
\hline 8 & University of Texas Health Science Center at San Antonio & 29 & 22 & $75.86 \%$ \\
\hline 9 & University of Zurich & 29 & 13 & $44.83 \%$ \\
\hline 10 & Academic Center for Dentistry Amsterdam & 28 & 11 & $39.29 \%$ \\
\hline
\end{tabular}

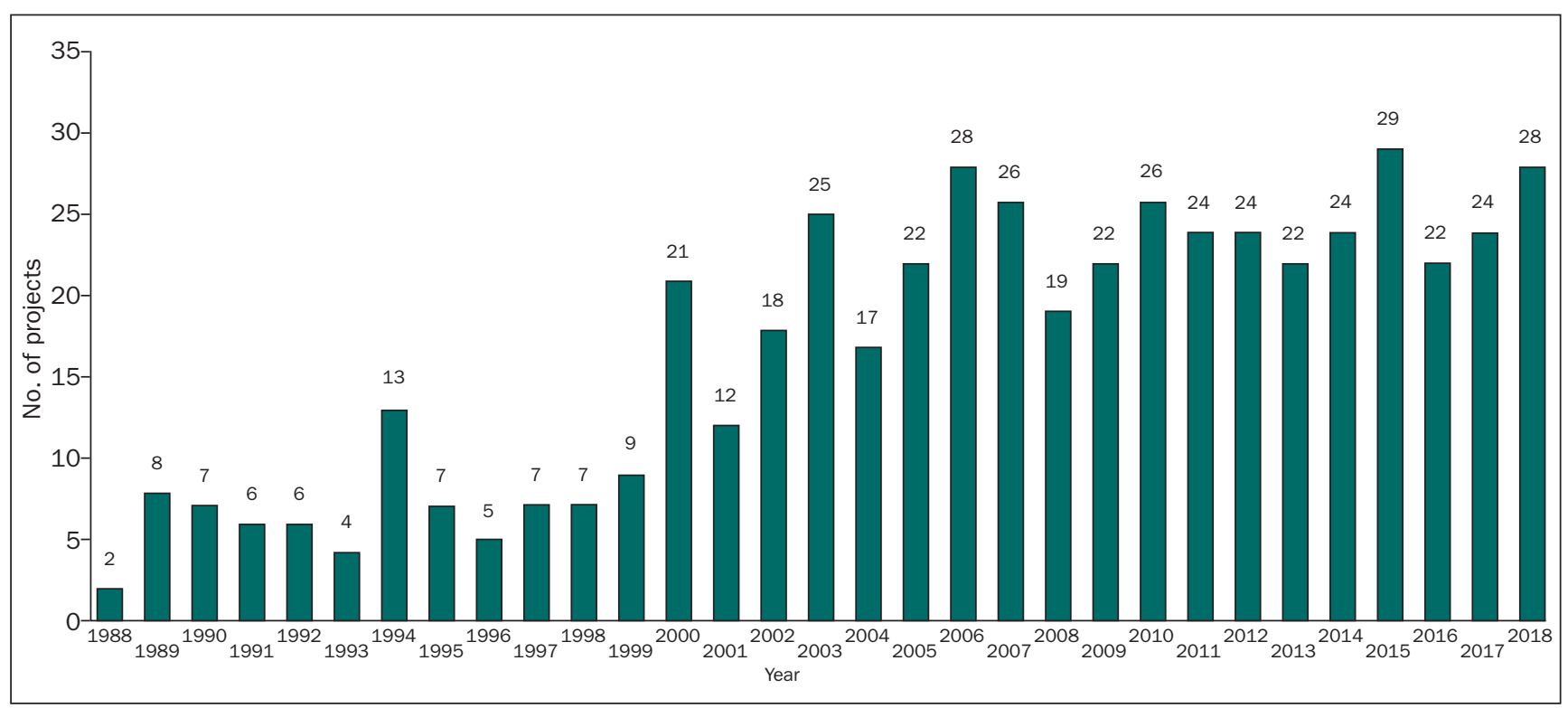

Fig 2 Number of projects financed by the ITI Foundation per year. 


\begin{tabular}{|c|c|c|c|c|}
\hline \multirow{3}{*}{$\begin{array}{l}\text { Table } 3 \\
\text { Publicatio }\end{array}$} & \multicolumn{4}{|c|}{$\begin{array}{l}\text { Number of Financed Projects } \\
\text { That Have Resulted in Scientific } \\
\text { Publication According to Project } \\
\text { Status }\end{array}$} \\
\hline & \multicolumn{3}{|c|}{ Project status } & \multirow{2}{*}{$\begin{array}{c}\text { Total no. } 0 \\
\text { projects }\end{array}$} \\
\hline & & Completed & Ongoing & \\
\hline \multicolumn{2}{|l|}{ Yes } & 298 & 19 & 317 \\
\hline \multicolumn{2}{|l|}{ No } & 83 & 114 & 197 \\
\hline \multicolumn{2}{|c|}{ No. of projects } & 381 & 133 & 514 \\
\hline
\end{tabular}

\begin{tabular}{|c|c|c|c|}
\hline Table 4 & $\begin{array}{l}\text { Top } 10 \text { Count } \\
\text { Originating fr } \\
\text { by the ITI Fou }\end{array}$ & $\begin{array}{l}\text { with } P \\
\text { a Proje } \\
\text { tion }\end{array}$ & $\begin{array}{l}\text { tions } \\
\text { anced }\end{array}$ \\
\hline Rank & Country & $\begin{array}{l}\text { No. of } \\
\text { articles }\end{array}$ & $\%$ \\
\hline 1 & USA & 122 & 22.10 \\
\hline 2 & Switzerland & 109 & 19.75 \\
\hline 3 & Germany & 77 & 13.95 \\
\hline 4 & China & 44 & 7.97 \\
\hline 5 & Austria & 21 & 3.80 \\
\hline 6 & Netherlands & 18 & 3.26 \\
\hline 7 & Italy & 17 & 3.08 \\
\hline 8 & Sweden & 17 & 3.08 \\
\hline 9 & Finland & 16 & 2.90 \\
\hline 10 & Denmark & 15 & 2.72 \\
\hline
\end{tabular}

\begin{tabular}{|llcr}
\hline Table $\mathbf{5}$ & $\begin{array}{l}\text { Top } \mathbf{1 0} \text { Institutional Affiliations } \\
\text { with Publications Originating } \\
\text { from a Project Financed by the ITI } \\
\text { Foundation }\end{array}$ & $\begin{array}{c}\text { No. of } \\
\text { articles }\end{array}$ & $\%$ \\
\hline Rank & $\quad$ Institutional affiliation & 57 & 10.33 \\
\hline 1 & University of Bern & 42 & 7.61 \\
\hline 2 & University of Texas Health Science & & \\
\hline 3 & Center at San Antonio & 26 & 4.71 \\
\hline 4 & University of Erlangen-Nuremberg & 21 & 3.80 \\
\hline 5 & Harvard University & 20 & 3.62 \\
\hline 6 & University of Vienna & 19 & 3.44 \\
\hline 7 & Private practice & 14 & 2.54 \\
\hline 8 & University of Mainz & 14 & 2.54 \\
\hline 9 & University of Copenhagen & 13 & 2.36 \\
\hline 10 & Wuhan University & 13 & 2.36 \\
\hline
\end{tabular}

\section{Publication-Related Information}

A total of 552 scientific publications could be identified in the literature related to 317 projects financed by the ITI Foundation.

The top three countries that contributed to the research publications were the United States (122 articles, 22.10\%), Switzerland (109 articles, 19.75\%), and Germany (77 articles, 13.95\%) (Table 4). The three highest contributing institutions were the University of Bern (57 articles, 10.33\%), University of Texas Health Science Center at San Antonio (42 articles, 7.61\%), and University of Erlangen-Nuremberg (26 articles, 4.71\%) (Table 5). In total, 33 countries and 130 different affiliations were listed in the publications. Appendix Tables 5 and 6 show the list of all countries and affiliations, respectively, related to the publications.

The research publications spanned over a total of 136 different journals. The vast majority of articles (153 articles, 27.72\%) were published in Clinical Oral Implants Research (COIR). The second and third most frequent journals were International Journal of Oral \& Maxillofacial Implants (JOMI) $(35,6.34 \%)$ and Journal of Periodontology (JOP) $(26,4.71 \%)$, respectively (Table 6). Appendix Table 7 shows the list of all journals.

Among all publications, in vitro studies accounted for the highest number as per this analysis, corresponding to $35.87 \%$ (198 articles) of the total publications, followed by animal studies (159 articles, 28.80\%), randomized controlled trials (RCTs) (42 articles, 7.61\%), case series (28 articles, 5.07\%), and review articles (21 articles, 3.80\%) (Fig 3). Preclinical papers accounted for $68.30 \%$ (377), while papers with clinical content accounted for $26.81 \%$ (148) of the total.

All publications were further classified into 30 different study topics based on the main objective of each study. The five topics with the most publications were: implant surface modification (114 articles, 20.65\%), basic research (67 articles, 12.14\%), tissue engineering (56 articles, 10.14\%), implant tissue interface (36 articles, 6.52\%), and systemic conditions (34 articles, $6.16 \%$ ) (Fig 4).

\section{Ranking and Citation Number}

The most-cited paper (1,171 citations) was "Influence of surface characteristics on bone integration of titanium implants. A histomorphometric study in miniature pigs," an animal study on implant surface modification published in the Journal of Biomedical Materials Research by Buser and colleagues (1991). ${ }^{31}$ Considering the average citations per year, this paper occupies the second position, with 41.82 citations per year. The paper with a higher yearly average, with 49.27, was “Enhanced bone apposition to a chemically modified SLA titanium surface," published in the Journal of Dental Research by Buser and coworkers in 2004, which is also an 


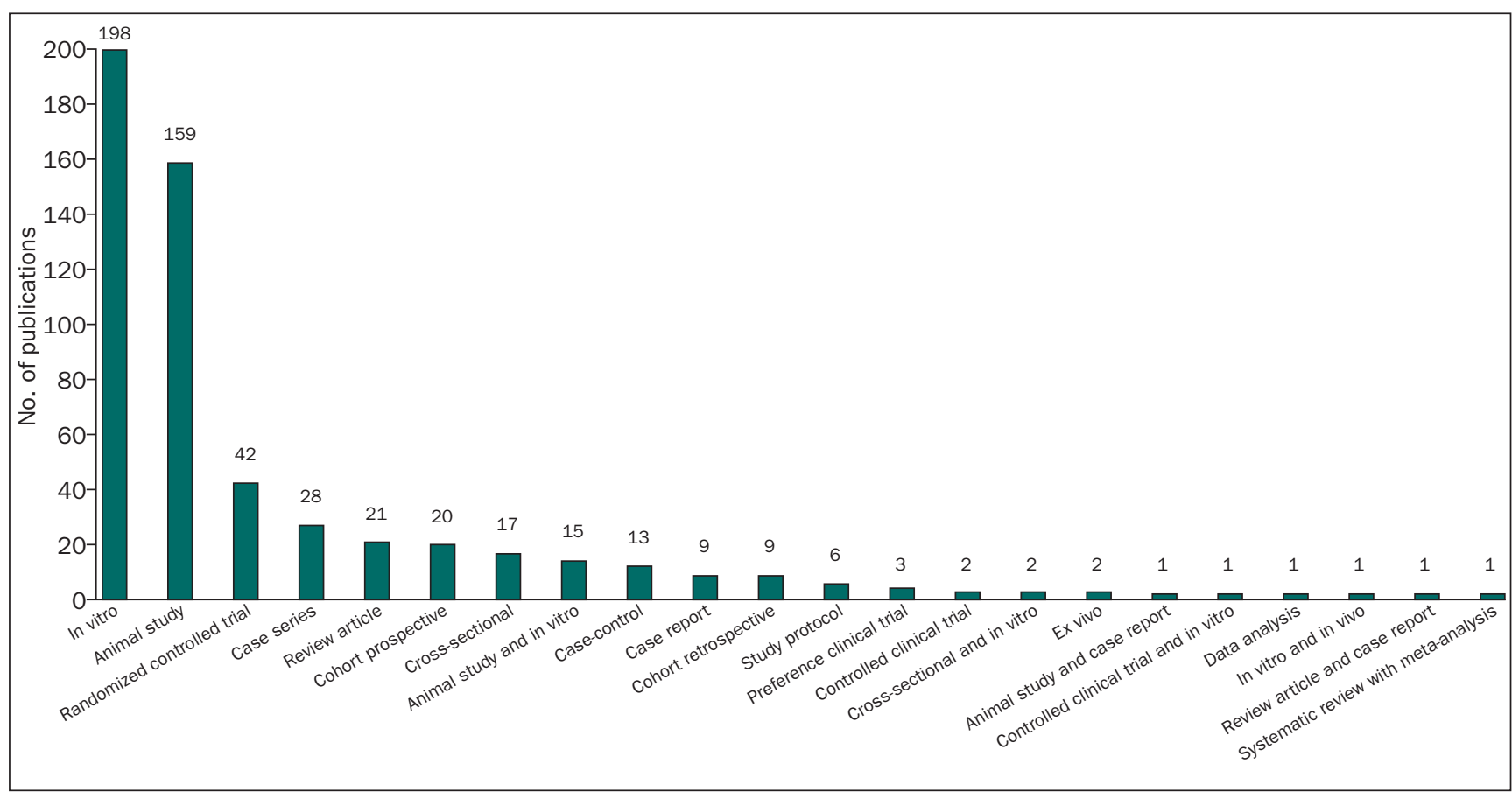

Fig 3 Proportions of the different study designs among the 552 articles originating from ITI Foundation-financed projects.

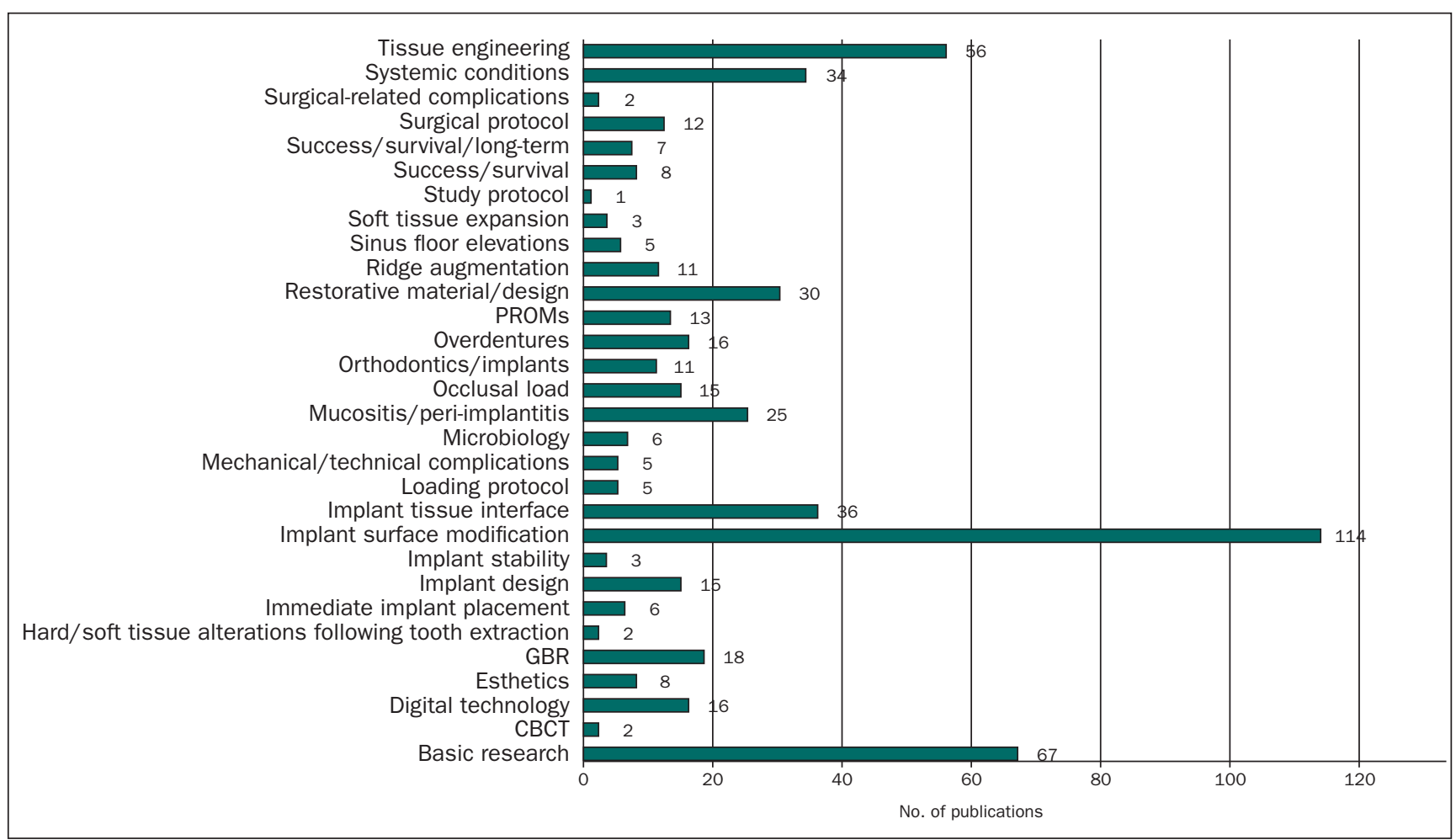

Fig 4 Proportions of the different study topics among the 552 articles originating from the ITI Foundation-financed projects. CBCT = cone beam computed tomography; GBR = guided bone regeneration; PROMs = patient-related outcome measures.

animal study on implant surface modification. ${ }^{32}$ Table 7 shows a list of the top 10 most-cited papers. The data for all 552 publications evaluated in the present study can be seen in Appendix Table 8.

\section{DISCUSSION}

In recent decades, there has been a drastic increase in the number of publications related to implant dentistry. 


\begin{tabular}{llcc} 
Table $\mathbf{6}$ & $\begin{array}{l}\text { Top } \mathbf{1 0} \text { Journals in Which Articles Originating from a Project Financed by the ITI } \\
\text { Foundation Are Published }\end{array}$ & \multicolumn{1}{c|}{ No. of articles } & Percentage (\%) \\
\hline Rank & \multicolumn{1}{c}{ Journal } & 153 & 27.72 \\
\hline 1 & Clinical Oral Implants Research & 35 & 6.34 \\
\hline 2 & International Journal of Oral \& Maxillofacial Implants & 26 & 4.71 \\
\hline 3 & Journal of Periodontology & 22 & 3.99 \\
\hline 4 & Journal of Dental Research & 21 & 3.80 \\
\hline 5 & Journal of Clinical Periodontology & 17 & 3.08 \\
\hline 6 & Biomaterials & 17 & 3.08 \\
\hline 7 & Journal of Biomedical Materials Research A & 15 & 2.72 \\
\hline 8 & Journal of Biomedical Materials Research & 11 & 1.99 \\
\hline 9 & Bone & 11 & 1.99 \\
\hline 10 & Clinical Implant Dentistry and Related Research & & \\
\hline
\end{tabular}

\section{Table 7 The 10 Most-Cited Articles of the Publications Financed by the ITI Foundation}

\begin{tabular}{|c|c|c|c|c|c|}
\hline Rank & Article & Study design & Study topic & Citations & $\begin{array}{l}\text { Citations } \\
\text { per year }\end{array}$ \\
\hline 1 & $\begin{array}{l}{ }^{31} \text { Buser D, Schenk RK, Steinemann S, Fiorellini JP, Fox CH, } \\
\text { Stich H. Influence of surface characteristics on bone } \\
\text { integration of titanium implants. A histomorphometric study } \\
\text { in miniature pigs. J Biomed Mater Res 1991;25:889-902. }\end{array}$ & Animal study & $\begin{array}{l}\text { Implant surface } \\
\text { modification }\end{array}$ & 1,171 & 41.82 \\
\hline 2 & $\begin{array}{l}{ }^{33} \text { Buser D, Mericske-Stern R, Bernard JP, et al. Long-term } \\
\text { evaluation of non-submerged ITI implants. Part 1: 8-year life } \\
\text { table analysis of a prospective multi-center study with } 2359 \\
\text { implants. Clin Oral Implants Res 1997;8:161-172. }\end{array}$ & $\begin{array}{l}\text { Cohort } \\
\text { prospective }\end{array}$ & $\begin{array}{l}\text { Success/ } \\
\text { survival/long- } \\
\text { term }\end{array}$ & 889 & 40.41 \\
\hline 3 & $\begin{array}{l}{ }^{34} \text { Martin JY, Schwartz Z, Hummert TW, et al. Effect of titanium } \\
\text { surface-roughness on proliferation, differentiation, and } \\
\text { protein-synthesis of human osteoblast-like cells (Mg63). J } \\
\text { Biomed Mater Res 1995;29:389-401. }\end{array}$ & In vitro & $\begin{array}{l}\text { Implant surface } \\
\text { modification }\end{array}$ & 777 & 32.28 \\
\hline 4 & $\begin{array}{l}{ }^{32} \text { Buser D, Broggini N, Wieland M, et al. Enhanced bone } \\
\text { apposition to a chemically modified SLA titanium surface. J } \\
\text { Dent Res } 2004 ; 83: 529-533 \text {. }\end{array}$ & Animal study & $\begin{array}{l}\text { Implant surface } \\
\text { modification }\end{array}$ & 739 & 49.27 \\
\hline 5 & $\begin{array}{l}{ }^{35} \text { Zhao G, Schwartz Z, Wieland M, et al. High surface } \\
\text { energy enhances cell response to titanium substrate } \\
\text { microstructure. J Biomed Mater Res A 2005;74:49-58. }\end{array}$ & In vitro & $\begin{array}{l}\text { Implant surface } \\
\text { modification }\end{array}$ & 557 & 39.79 \\
\hline 6 & $\begin{array}{l}{ }^{36} \text { Buser D, Weber HP, Lang NP. Tissue integration of non- } \\
\text { submerged implants. 1-year results of a prospective study } \\
\text { with } 100 \text { ITI hollow-cylinder and hollow-screw implants. Clin } \\
\text { Oral Implants Res 1990;1:33-40. }\end{array}$ & $\begin{array}{l}\text { Cohort } \\
\text { prospective }\end{array}$ & $\begin{array}{l}\text { Success/ } \\
\text { survival }\end{array}$ & 509 & 17.55 \\
\hline 7 & $\begin{array}{l}{ }^{37} \text { Cochran DL, Schenk RK, Lussi A, Higginbottom FL, Buser D. } \\
\text { Bone response to unloaded and loaded titanium implants } \\
\text { with a sandblasted and acid-etched surface: A histometric } \\
\text { study in the canine mandible. J Biomed Mater Res } \\
\text { 1998;40:1-11. }\end{array}$ & Animal study & $\begin{array}{l}\text { Implant surface } \\
\text { modification }\end{array}$ & 438 & 20.86 \\
\hline 8 & $\begin{array}{l}{ }^{38} \text { Kieswetter K, Schwartz Z, Hummert TW, et al. Surface } \\
\text { roughness modulates the local production of growth factors } \\
\text { and cytokines by osteoblast-like MG-63 cells. J Biomed } \\
\text { Mater Res } 1996 ; 32: 55-63 \text {. }\end{array}$ & In vitro & $\begin{array}{l}\text { Implant surface } \\
\text { modification }\end{array}$ & 437 & 19 \\
\hline 9 & $\begin{array}{l}{ }^{39} \text { Berglundh T, Abrahamsson I, Lang NP, Lindhe J. De novo } \\
\text { alveolar bone formation adjacent to endosseous implants. } \\
\text { Clin Oral Implants Res 2003;14:251-262. }\end{array}$ & Animal study & $\begin{array}{l}\text { Implant tissue } \\
\text { interface }\end{array}$ & 421 & 26.31 \\
\hline 10 & $\begin{array}{l}{ }^{40} \text { Rupp F, Scheideler L, Olshanska N, de Wild M, Wieland } \\
\text { M, Geis-Gerstorfer J. Enhancing surface free energy } \\
\text { and hydrophilicity through chemical modification of } \\
\text { microstructured titanium implant surfaces. J Biomed Mater } \\
\text { Res A 2006;76:323-334. }\end{array}$ & In vitro & $\begin{array}{l}\text { Implant surface } \\
\text { modification }\end{array}$ & 371 & 28.54 \\
\hline
\end{tabular}


This increase is synonymous with progress in the science of implantology, and is responsible for improving treatment outcomes with dental implants. A source of funding is essential for such increase in research, and it could be availed from various avenues. The ITI Foundation, a scientifically independent, noncommercial organization, has been actively supporting research in implant dentistry for the past 30 years, and there was an interest in analyzing the contributions made by this organization to the field. It is important for an organization to have a clear evidence-based understanding of its performance toward its mission based on an evaluation of its ongoing functions. This helps the organization understand its position related to the research conducted, its impact, authors involved, and if the publications are increasing or decreasing. This provides a basis toward setting goals, monitoring change and progress, making budgetary decisions, and investing in facilities. This analysis showed that the ITI Foundation has invested more than CHF 52 million in 514 scientific projects related to implant dentistry, making it one of the largest nongovernmental organizations to support research in the field. Over the past decade, the number of projects financed and the number of publications has progressively increased with approximately $40 \%$ of the total projects accepted for funding. This bibliometric analysis of quantitative and weighted quantitative analysis (citation number) of research supported by the ITI over the years provides a comprehensive view on the activity and achievements.

The present analysis shows that the three countries-United States, Germany, and Switzerland - with the largest number of submitted projects were also the ones with most projects financed and with the highest number of publications. Other authors have also found that the developed countries, especially from North America and Europe, have a higher number of implant-related publications. ${ }^{26,27,41,42} \mathrm{It}$ is also interesting to note that the developing countries, such as China, Brazil, and India, made it to the top 10 countries for project submissions. Research outcomes from countries depend on the percentage of the Gross Domestic Product (GDP) spent on research. ${ }^{43}$ In developed countries, higher percentages are allotted for research; such countries may have a higher number of active research groups competing for grants. It has also been observed that research scholars and scientists migrate from their home countries to North America or Europe, and this may also add to the increased numbers. ${ }^{44}$ The authors speculate that this may also be related to the growth of the ITI. As previously mentioned, when the association was founded in 1980, the 12 experts from the field of implant dentistry were all from Switzerland or Germany. The ITI has slowly gained popularity outside Europe, and the USA section was the first to be created outside Europe. Later, different sections were created around the world. With awareness to the ITI increasing only over the last 10 to 15 years in South American and Asian countries, it is possible that this cumulative analysis shows lower numbers of applications from these countries.

The University of Bern was the institution with the highest number of projects submitted and financed. Being the home university of Prof Andre Schroeder, the co-founder and first president of the ITI, this university was an early and significant applicant for research funds from the ITI. Private practice accounted for the second highest and University of Mainz the third. Many of the top 10 institutions were scholarship centers recognized by the ITI as centers directed by experts in the field of implant dentistry. A scholarship center is a university (department) that the ITI has partnered up with within the framework of the ITI Scholarship Program that hosts ITI Scholars. It is possible that these centers had active research faculty, international collaborations, and/or students/professional exchanges that accounted for the higher number of research projects and publications. ${ }^{25,26,42}$ It could be possible that ITI scholarships increased the pattern for collaboration, with active centers yielding a higher amount of research.

It is also interesting to note that although most completed projects had a publication, about $20 \%$ of the projects did not result in any publication. This is of concern to the ITI, who specifies that the outcome of the funded project has to be a publication. However, as mentioned, in this analysis, the publications stored in the database were used, and additional publications were identified based on the acknowledgment stated by the authors related to funding. It is possible that some authors either did not provide the publicationrelated information to the ITI or that publications did not carry the acknowledgment and hence were not considered, or may have also been in another language and hence could not be identified.

Among the countries with the most publications, the top four were the United States, Switzerland, Germany, and China. The United States has also been considered as the most productive country for implant literature in a previous study. ${ }^{25}$ The Scandinavian countries Sweden, Finland, and Denmark were also in the list, despite not being in the list of top 10 countries applying for grants to the ITI. This is not surprising, as other authors have stated that Scandinavian countries are extremely productive in terms of publications. ${ }^{41,45}$ It is also important to note that just quantitative findings do not necessarily mean the qualitative parameters are high as well. ${ }^{41}$ The total number of publications from all projects was highest from the University of Bern, with an average number of one publication per 
project. Most of the other universities in the highest publication list were also in the top 10 applying for grants. It is interesting to note that Wuhan University - China did not figure in the top 10 universities for grant acceptance, but had the 10th position in publication numbers with a total of 13 publications. A trend for increase in publications from Asian countries has been observed, ${ }^{46}$ and the present study also seconds that. One drawback in this analysis was that for several studies, there was no clear mention of the address the study was conducted in, and hence, the first affiliation of the first author was considered; thus, there is a chance in underestimation of some institutions and/ or overrepresentations of others. Several publications (52\%) had international collaborations, which is in sync with the vision of the ITI for connecting people around the globe through implant dentistry.

The vast majority of articles were published in the journal Clinical Oral Implants Research (COIR). Other exclusive implant journals such as International Journal of Oral \& Maxillofacial Implants and Clinical Implant Dentistry and Related Research figured in the top 10. Popular periodontology journals and journals related to material science also figured in the top 10. Other authors have observed that when research groups come from Europe or North America, they prefer to submit their publications to journals with editorial boards in the same continents. ${ }^{26,47}$ This analysis shows a similar pattern.

Bibliometric analysis gives a large amount of information, such as the trends in frequently studied topics, 48,49 trends in study design, ${ }^{48,50}$ type of articles and authorship trends, ${ }^{47,51}$ evolution of research activity, ${ }^{52}$ geographic origin of research articles, ${ }^{48}$ or information specifically oriented to certain diseases or conditions. ${ }^{53,54}$ The present study demonstrated that the vast majority of publications were in vitro and animal research (preclinical research), while a relatively lower percentage of publications were clinical. Preclinical research is performed to evaluate biologic mechanisms, treatment strategies, safety, and possible adverse event reactions to candidate materials/technologies/ devices prior to clinical research. ${ }^{55}$ National organizations such as the European Medicine Agency (EMA) and the US Food and Drug Administration (FDA) mandate preclinical research before giving clearance for human trials. In the present study, the numbers of in vitro studies and animal studies were high, suggesting that evaluation of materials and processes, both biologic and nonbiologic, and new treatment modalities, had a high level of importance in the funded research. This is suggestive that the ITI Foundation has actively supported the validation of biologic materials and processes as well as development of new technologies and devices in implant dentistry. Also, animal and in vitro studies require a lower individual amount compared with clinical studies, which demand higher financial support ${ }^{26}$; hence, the increased number of preclinical publications compared with clinical publications can be related to this.

The most published topic was implant surface modification. Over the years, it is apparent that modification of implant surfaces to achieve faster osseointegration has been an important topic of research. In fact, 8 of the top 10 cited papers are related to preclinical studies evaluating implant surface modifications. $31,32,34,35,37-40$ The most-cited paper from this analysis is considered a landmark preclinical study in implant surface technology and established the importance of a microrough surface in osseointegration. ${ }^{31}$ When considering the yearly citations per article, the one with the highest number of citations per year (49.27 citations/year) was also on implant surface modifications ${ }^{32}$ and is another landmark study in implant surface technology.

In dentistry, bibliometric analysis of the highest cited papers has been performed by other authors analyzing the publications in the field of general dentistry, ${ }^{56}$ implant dentistry, ${ }^{30,42}$ periodontology, ${ }^{57-60}$ endodontics, ${ }^{61-63}$ orthodontics, ${ }^{64,65}$ and oral and maxillofacial surgery. ${ }^{66-68}$

Citation number may be a sign of the impact that the article has made on the scientific community and has been a widely used measure of recognition received. ${ }^{67}$ Although the number of citations does not measure the quality of the research, ${ }^{60,69}$ a highly cited paper can represent a landmark paper on a specific topic. In this study, the number of citations were retrieved from the ISI Web of Science, an online platform widely accepted and used for this purpose. ${ }^{30,42,56-66,69}$ However, this platform has its own limitations, such as not excluding self-citations, which contribute extensively to the total number of citations and average citations per year; it favors English language articles and journals. This may have a direct influence on the results and should be taken into account during consideration of the impact of an article.

In order to reduce the risk of bias, the methodology described in this study was followed. However, the authors recognize that errors may still be present and that the study has some limitations. As mentioned earlier, the publications assessed in this study were obtained mainly from the ITI Database, which has been updated over the past 30 years based on publication information furnished by the research groups. With communication technology being less advanced in the 1990s, it is possible that publications from the early projects missed documentation. Therefore, there may be a possibility that the total number of publications present here is underestimated. In addition, only papers published in scientific journals were considered for this 
analysis. Abstracts, posters, books, and book chapters were not included, which could further increase the impact of ITI in terms of scientific production.

It is clear that the number of scientific publications related to implant dentistry has been growing, as well as the sale of dental implants. It is estimated that approximately 12 to 18 million dental implants are sold worldwide each year from more than 100 commercial companies. ${ }^{70}$ The authors assume that one of the reasons for this is the growing awareness that implants are a successful long-term solution to replace missing teeth, as proven by the body of scientific evidence. The present study did not consider/evaluate questions related to the sale of dental implants and the possible influence of the development of the dental implant market on the development of the number of scientific publications, nor publications arising from funding organizations other than the ITI or from direct companyfunded research. Only the projects and publications funded by the ITI were analyzed. Therefore, it is not possible within the scope of this paper to make any statements as to the possible correlation of the dental implant market with the total number of publications in the area of implant dentistry.

The ITI Foundation continues to be one of the largest organizations working toward the global developments in the field of oral implantology. It has made a significant contribution to the progress and development of implant technology and clinical science over the past decades and has helped in its evolution. ITIfunded research provided evidence and information to clinicians to select various strategies and materials for treatment that made implant dentistry predictable, and this has enhanced market growth of related products. Financial support provided by the ITI to scientific researchers and clinicians by means of research grants has been the backbone of several game-changing publications in the field. Overall, the outcome of research projects has been a worthwhile investment for the organization, in line with its mission of providing a growing global network in implant dentistry through innovative research, for the benefit of the patient. Such organizations are invaluable to promising researchers requiring extramural funding.

\section{CONCLUSIONS}

This analysis revealed that the ITI has been actively supporting research in the field of implant dentistry and related areas globally, with more than CHF 50 million invested in several research projects from 31 different countries and 146 different institutional affiliations. In addition, several concepts in present-day implantology are based on literature from ITI-funded projects, as a result of the 552 scientific publications (pre-clinical and clinical research) that could be identified in the present analysis.

\section{ACKNOWLEDGMENTS}

The authors thank Mrs Deborah Bader, from the ITI Headquarters, for the invaluable assistance provided throughout the project; Dr Qin Yue for the help with the Chinese publications; and Mrs Sandra Schnyder, librarian of the University of Bern, for providing the files of some publications. The authors have stated explicitly that there are no conflicts of interest in connection with this article. The study was funded by the authors, their institution, and the ITI Foundation.

\section{REFERENCES}

1. Brånemark $\mathrm{PI}$, Hansson $\mathrm{BO}$, Adell R, et al. Osseointegrated implants in the treatment of the edentulous jaw. Experience from a 10-year period. Scand J Plast Reconstr Surg Suppl 1977;16:1-132.

2. Adell R, Lekholm U, Rockler B, Brånemark PI. A 15-year study of osseointegrated implants in the treatment of the edentulous jaw. Int J Oral Surg 1981;10:387-416.

3. Dierens M, Vandeweghe S, Kisch J, Nilner K, De Bruyn H. Longterm follow-up of turned single implants placed in periodontally healthy patients after 16-22 years: Radiographic and peri-implant outcome. Clin Oral Implants Res 2012;23:197-204.

4. Gotfredsen K. A 10-year prospective study of single tooth implants placed in the anterior maxilla. Clin Implant Dent Relat Res 2012;14:80-87.

5. Pjetursson BE, Thoma D, Jung R, Zwahlen M, Zembic A. A systematic review of the survival and complication rates of implant-supported fixed dental prostheses (FDPs) after a mean observation period of at least 5 years. Clin Oral Implants Res 2012;23(suppl 6):22-38.

6. Chappuis V, Buser R, Brågger U, Bornstein MM, Salvi GE, Buser D. Long-term outcomes of dental implants with a titanium plasmasprayed surface: A 20-year prospective case series study in partially edentulous patients. Clin Implant Dent Relat Res 2013;15:780-790.

7. Schropp L, Wenzel A, Stavropoulos A. Early, delayed, or late single implant placement: 10-year results from a randomized controlled clinical trial. Clin Oral Implants Res 2014;25:1359-1365.

8. van Velzen FJ, Ofec R, Schulten EA, Ten Bruggenkate CM. 10-year survival rate and the incidence of peri-implant disease of 374 titanium dental implants with a SLA surface: A prospective cohort study in 177 fully and partially edentulous patients. Clin Oral Implants Res 2015;26:1121-1128.

9. Vandeweghe S, Ferreira D, Vermeersch L, Mariën M, De Bruyn H. Long-term retrospective follow-up of turned and moderately rough implants in the edentulous jaw. Clin Oral Implants Res 2016;27:421-426.

10. Raes S, Cosyn J, Noyelle A, Raes F, De Bruyn H. Clinical outcome after 8 to 10 years of immediately restored single implants placed in extraction sockets and healed ridges. Int J Periodontics Restorative Dent 2018;38:337-345.

11. Raes S, Eghbali A, Chappuis V, Raes F, De Bruyn H, Cosyn J. A longterm prospective cohort study on immediately restored single tooth implants inserted in extraction sockets and healed ridges: $C B C T$ analyses, soft tissue alterations, aesthetic ratings, and patientreported outcomes. Clin Implant Dent Relat Res 2018;20:522-530.

12. Srinivasan M, Meyer S, Mombelli A, Müller F. Dental implants in the elderly population: A systematic review and meta-analysis. Clin Oral Implants Res 2017;28:920-930.

13. Daudt Polido W, Aghaloo T, Emmett TW, Taylor TD, Morton D. Number of implants placed for complete-arch fixed prostheses: A systematic review and meta-analysis. Clin Oral Implants Res 2018;29(suppl 16):154-183. 
14. Pieralli S, Kohal RJ, Rabel K, von Stein-Lausnitz M, Vach K, Spies $B C$. Clinical outcomes of partial and full-arch all-ceramic implantsupported fixed dental prostheses. A systematic review and metaanalysis. Clin Oral Implants Res 2018;29(suppl 18):224-236.

15. Storelli S, Del Fabbro M, Scanferla M, Palandrani G, Romeo E. Implant-supported cantilevered fixed dental rehabilitations in fully edentulous patients: Systematic review of the literature. Part II. Clin Oral Implants Res 2018;29(suppl 18):275-294.

16. Gallucci GO, Hamilton A, Zhou W, Buser D, Chen S. Implant placement and loading protocols in partially edentulous patients: A systematic review. Clin Oral Implants Res 2018;29(suppl 16):106-134.

17. Storelli S, Del Fabbro M, Scanferla M, Palandrani G, Romeo E. Implant supported cantilevered fixed dental rehabilitations in partially edentulous patients: Systematic review of the literature. Part I. Clin Oral Implants Res 2018;29(suppl 18):253-274.

18. Chappuis V, Rahman L, Buser R, Janner SFM, Belser UC, Buser D. Effectiveness of contour augmentation with guided bone regeneration: 10-year results. J Dent Res 2018;97:266-274.

19. Rabel K, Spies BC, Pieralli S, Vach K, Kohal RJ. The clinical performance of all-ceramic implant-supported single crowns: A systematic review and meta-analysis. Clin Oral Implants Res 2018;29(suppl 18):196-223.

20. Brånemark PI, Adell R, Breine U, Hansson BO, Lindström J, Ohlsson A. Intra-osseous anchorage of dental prostheses. I. Experimental studies. Scand J Plast Reconstr Surg 1969;3:81-100.

21. Schroeder A, Pohler O, Sutter F. Gewebsreaktion auf ein TitanHohlzylinderimplantat mit Titan-Spritzschichto-berfläche. Schweiz Monatsschr Zahnmed 1976;86:713-727.

22. Schroeder A, van der Zypen E, Stich $H$, Sutter F. The reactions of bone, connective tissue, and epithelium to endosteal implants with titanium-sprayed surfaces. J Maxillofac Surg 1981;9:15-25.

23. Buser D, Sennerby L, De Bruyn H. Modern implant dentistry based on osseointegration: 50 years of progress, current trends and open questions. Periodontol 2000 2017;73:7-21.

24. Pulgar R, Jiménez-Fernández I, Jiménez-Contreras E, Torres-Salinas D, Lucena-Martín C. Trends in World Dental Research: An overview of the last three decades using the Web of Science. Clin Oral Investig 2013;17:1773-1783.

25. Tarazona B, Vidal-Infer A, Alonso-Arroyo A. Bibliometric analysis of the scientific production in implantology (2009-2013). Clin Oral Implants Res 2017;28:864-870.

26. Barão VA, Shyamsunder N, Yuan JC, Knoernschild KL, Assunção WG, Sukotjo C. Trends in funding, internationalization, and types of study for original articles published in five implant-related journals between 2005 and 2009. Int J Oral Maxillofac Implants 2012;27:69-76.

27. Yuan JC, Shyamsunder N, Barao VA, Lee DJ, Sukotjo C. Publication bias in five dental implant journals: An observation from 2005 to 2009. Int J Oral Maxillofac Implants 2011;26:1024-1032.

28. Popelut A, Valet F, Fromentin O, Thomas A, Bouchard P. Relationship between sponsorship and failure rate of dental implants: $A$ systematic approach. PloS One 2010;5:e10274.

29. Busslinger A. The International Team for Implantology (ITI) Research Foundation - A retrospective analysis of research grants allocated in the years 1988-2006 [dissertation]. ITI International Team for Implantology: University of Bern, 2006.

30. Alarcon MA, Esparza D, Montoya C, Monje A, Faggion CM Jr. The 300 most-cited articles in implant dentistry. Int J Oral Maxillofac Implants 2017;32:e1-e8.

31. Buser D, Schenk RK, Steinemann S, Fiorellini JP, Fox CH, Stich H. Influence of surface characteristics on bone integration of titanium implants. A histomorphometric study in miniature pigs. J Biomed Mater Res 1991;25:889-902.

32. Buser D, Broggini N, Wieland M, et al. Enhanced bone apposition to a chemically modified SLA titanium surface. J Dent Res 2004;83:529-533.

33. Buser D, Mericske-Stern R, Bernard JP, et al. Long-term evaluation of non-submerged ITI implants. Part 1: 8-year life table analysis of a prospective multi-center study with 2359 implants. Clin Oral Implants Res 1997;8:161-172.

34. Martin JY, Schwartz Z, Hummert TW, et al. Effect of titanium surface-roughness on proliferation, differentiation, and proteinsynthesis of human osteoblast-like cells (Mg63). J Biomed Mater Res 1995;29:389-401.
35. Zhao G, Schwartz Z, Wieland M, et al. High surface energy enhances cell response to titanium substrate microstructure. J Biomed Mater Res A 2005;74:49-58.

36. Buser D, Weber HP, Lang NP. Tissue integration of non-submerged implants. 1-year results of a prospective study with 100 ITI hollow-cylinder and hollow-screw implants. Clin Oral Implants Res 1990;1:33-40.

37. Cochran DL, Schenk RK, Lussi A, Higginbottom FL, Buser D. Bone response to unloaded and loaded titanium implants with a sandblasted and acid-etched surface: A histometric study in the canine mandible. J Biomed Mater Res 1998;40:1-11.

38. Kieswetter K, Schwartz Z, Hummert TW, et al. Surface roughness modulates the local production of growth factors and cytokines by osteoblast-like MG-63 cells. J Biomed Mater Res 1996;32:55-63.

39. Berglundh T, Abrahamsson I, Lang NP, Lindhe J. De novo alveolar bone formation adjacent to endosseous implants. Clin Oral Implants Res 2003;14:251-262.

40. Rupp F, Scheideler L, Olshanska N, de Wild M, Wieland M, GeisGerstorfer J. Enhancing surface free energy and hydrophilicity through chemical modification of microstructured titanium implant surfaces. J Biomed Mater Res A 2006;76:323-334.

41. Gil-Montoya JA, Navarrete-Cortes J, Pulgar R, Santa S, MoyaAnegón F. World dental research production: An ISI database approach (1999-2003). Eur J Oral Sci 2006;114:102-108.

42. Fardi A, Kodonas K, Lillis T, Veis A. Top-cited articles in implant dentistry. Int J Oral Maxillofac Implants 2017;32:555-564.

43. Meo SA, Al Masri AA, Usmani AM, Memon AN, Zaidi SZ. Impact of GDP, spending on $R \& D$, number of universities and scientific journals on research publications among Asian countries. PloS One 2013;8:e66449.

44. Van Noorden R. Global mobility: Science on the move. Nature 2012;490:326-329.

45. Hefler L, Tempfer C, Kainz C. Geography of biomedical publications in the European Union, 1990-98. Lancet (London, England) 1999;353:1856.

46. Yuan JC, Lee DJ, Knoernschild KL, Campbell SD, Sukotjo C. Authorship characteristics in prosthodontic literature: Proliferation and internationalization. A review and analysis following a 10-year observation. J Prosthet Dent 2010;104:158-164.

47. Kanavakis G, Spinos P, Polychronopoulou A, Eliades T, PapadopouIos MA, Athanasiou AE. Orthodontic journals with impact factors in perspective: Trends in the types of articles and authorship characteristics. Am J Orthod Dentofacial Orthop 2006;130:516-522.

48. Geminiani A, Ercoli C, Feng C, Caton JG. Bibliometrics study on authorship trends in periodontal literature from 1995 to 2010. J Periodontol 2014;85:e136-e143.

49. Pommer B, Valkova V, Ubaidha Maheen C, Fürhauser L, RauschFan X, Seeman R. Scientific interests of 21st century clinical oral implant research: Topical trend analysis. Clin Implant Dent Relat Res 2016;18:850-856.

50. Del Fabbro M, Corbella S, Tsesis I, Taschieri S. The trend of quality of publications in endodontic surgery: A 10-year systematic survey of the literature. J Evid Based Dent Pract 2015;15:2-7.

51. Baumgartner S, Pandis N, Eliades T. Exploring the publications in three major orthodontic journals: A comparative analysis of two 5-year periods. Angle Orthod 2014;84:397-403.

52. Gutiérrez-Vela MM, Díaz-Haro A, Berbel-Salvador S, LuceroSánchez A, Robinson-García N, Cutando-Soriano A. Bibliometric analysis of research on regenerative periodontal surgery during the last 30 years. J Clin Exp Dent 2012;4:e112-e118.

53. Gondivkar SM, Sarode SC, Gadbail AR, Gondivkar RS, Chole R, Sarode GS. Bibliometric analysis of 100 most cited articles on oral submucous fibrosis. J Oral Pathol Med 2018;47:781-787.

54. Hafeez MS, Malik AT, Noordin S. The top 100 most-cited articles on osteosarcoma: A bibliometric analysis. IJS Oncology 2018;3:e62.

55. Berglundh T, Stavropoulos A; Working Group 1 of the VIII European Workshop on Periodontology. Preclinical in vivo research in implant dentistry. Consensus of the eighth European workshop on periodontology. J Clin Periodontol 2012;39(suppl 12):1-5.

56. Feijoo JF, Limeres J, Fernández-Varela M, Ramos I, Diz P. The 100 most cited articles in dentistry. Clin Oral Investig 2014;18:699-706.

57. Nieri M, Saletta D, Guidi L, et al. Citation classics in periodontology: A controlled study. J Clin Periodontol 2007;34:349-358. 
58. Faggion CM Jr, Málaga L, Monje A, Trescher AL, Listl S, Alarcón MA. The 300 most cited articles published in periodontology. Clin Oral Investig 2017;21:2021-2028.

59. Corbella S, Francetti L, Taschieri S, Weinstein R, Del Fabbro M. Analysis of the 100 most-cited articles in periodontology. J Investig Clin Dent 2017;8.

60. Chiang HS, Huang RY, Weng PW, et al. Increasing prominence of implantology research: A chronological trend analysis of 100 top-cited articles in periodontal journals. Eur J Oral Implantol 2018;11:97-110.

61. Fardi A, Kodonas K, Gogos C, Economides N. Top-cited articles in endodontic journals. J Endod 2011;37:1183-1190.

62. Adnan S, Ullah R. Top-cited articles in regenerative endodontics: A bibliometric analysis. J Endod 2018;44:1650-1664.

63. Ahmad P, Dummer PMH, Noorani TY, Asif JA. The top 50 most-cited articles published in the International Endodontic Journal. Int Endod J 2019;52:803-818.

64. Hui J, Han Z, Geng G, Yan W, Shao P. The 100 top-cited articles in orthodontics from 1975 to 2011. Angle Orthod 2013;83:491-499.
65. Tarazona B, Lucas-Dominguez R, Paredes-Gallardo V, Alonso-Arroyo A, Vidal-Infer A. The 100 most-cited articles in orthodontics: A bibliometric study. Angle Orthod 2018;88:785-796.

66. Jafarzadeh H, Sarraf Shirazi A, Andersson L. The most-cited articles in dental, oral, and maxillofacial traumatology during 64 years. Dent Traumatol 2015;31:350-360.

67. Aslam-Pervez N, Lubek JE. Most cited publications in oral and maxillofacial surgery: A bibliometric analysis. Oral Maxillofac Surg 2018;22:25-37.

68. Susarla SM, Tveit M, Dodson TB, Kaban LB, Hopper RA, Egbert MA. What are the defining characteristics of the most cited publications in orthognathic surgery? Int J Oral Maxillofac Surg 2018;47:1411-1419.

69. Seglen PO. Citation rates and journal impact factors are not suitable for evaluation of research. Acta Orthop Scand 1998;69:224229.

70. Klinge B, Lundström M, Rosén M, Bertl K, Klinge A, Stavropoulos A. Dental Implant Quality Register-A possible tool to further improve implant treatment and outcome. Clin Oral Implants Res 2018;29(suppl 18):145-151. 